\title{
The Relationship between Somatotype and Dietary Intake of 6 to 13 Years Old Rural South African Children: Ellisras Longitudinal Study KD Monyeki ${ }^{1}$, NE Ramoshaba ${ }^{1}$, HGC Kemper ${ }^{2}$
}

\begin{abstract}
Objectives: Development of obesity related to dietary intake was linked to four stages of human growth. The aim of this study was to investigate the relationship between somatotype and dietary intake of Ellisras rural children aged 6 to 13 years.

Methods: Data were used from 773 children [400 boys, 373 girls], aged 6-13 years, participating in the Ellisras Longitudinal Study. The Heath-Carter method of somatotyping was used. Dietary intake was measured using the $24 \mathrm{~h}$ recall method. The recommended daily dietary allowance according to the Food and Agriculture Organization [FAO] was used as cut-off points for high and low dietary intake.
\end{abstract}

Results: The ectomorphy rating was significantly high [6.3] in the mild group compared to other groups [ranges from 2.6 to 5.6]. The prevalence of low polyunsaturated fat was significantly high [71.4\%] in the obese group compared to all other groups [ranges from 60.0 to $70.3 \%$ ]. Ellisras rural children showed that total Protein $[$ Beta $=0.00295 \%$ CI 0.00 to 0.004$]$ and Energy $[\mathrm{Beta}=0.00195 \% \mathrm{CI} 0.000 .010]$ were significantly $[\mathrm{P}<0.05]$ related to endomorphy for unadjusted while Viatmine E (Beta=0.01 95\%CI 0.00 to 0.021$)$ was significantly $[\mathrm{P}<0.04]$ associated with ectomorphy unadjusted for age and gender

Conclusion: Energy intake and total protein intake were significantly $[\mathrm{P}<0.01]$ related to endomorphy while Vitamin E was significantly $[\mathrm{P}<0.04]$ associated with ectomorphy. Future research should clarify how healthy are these children and how healthy is their lifestyle with respect to diet, physical activity, smoking and alcohol consumption today.

Keywords: Diet, rural South African children, somatotype, under nutrition

From: ${ }^{1}$ Physiology and Environment Health, University of Limpopo, Sovenga, 0727, South Africa ${ }^{2}$ VU University Medical Centre, Institute for Care and Health Research in Extramural Medicine (EMGO), Amsterdam, the Netherlands.

Correspondence: Dr KD Monyeki, Department of Physiology and Environmental Health, University of Limpopo, Turfloop Campus Private Bag X1106, Sovenga 0727. E-mail: dmonyeki@ yahoo.com or kotsedi.monyeki@ul.ac.za 


\section{INTRODUCTION}

Somatotyping is one of the most useful methods of evaluating physique. It is a quantification of the present shape and composition of the human body in terms of endomorphy [relative fatness], mesomorphy [relative muscularity robustness] and ectomorphy [relative linearity] (1). Obesity or overweight is a condition of excess fat. Obesity in most people owes to energy intake in their diet has over a period, exceeded their energy expenditure in metabolism, movement and growth. Indirect causes are often complex and are sometimes linked to psychological factors, social expectation or pressure and fat stigmatization $(2,3)$. Dietz (4) reported the short term consequences of obesity in children as often attributed to psychological stress such as low esteem, poor peer acceptance and low participation in social and sport activities. However, in some African cultures particularly those living in rural areas and a minority in urban who still follow indigenous knowledge, regard obesity in both children and adult as a sign of wealth, status and physical attractiveness (5). In reality obesity and overweight increase the risk of various cardiovascular problems. For example, increase in body mass index $[\mathrm{BMI}]$ is often an independent risk factor for the development of elevated blood pressure, clustering of various cardiovascular risk factors in metabolic syndrome, type 2 diabetes, abnormal vascular wall thickness, endothelial dysfunction of left ventricular hypertrophy, high lifetime risk of hypertension, coronary heart diseases, stroke, respiratory problem, and some cancers $(6,7)$. However the relationship between somatotype and dietary intake has received a little attention in rural South African children.

The existing patterns of under- and over nutrition, particularly in children from middleincome and developing countries, is recognized by the International Obesity Task Force [IOTF] and the World Health Organization [WHO] as one of the top 10 future health 
problems (8). In the developing countries child under nutrition is a leading risk factor underlying child morbidity and mortality (9). Therefore, information about the relationship between somatotype and dietary intake of the 6 to 13 years old primary school children, especially in rural countries like Ellisras could shed more light in this area. The purpose of this study was therefore to determine the relationship between somatotype and dietary intake of 6 to13 years old primary school children in Ellisras rural areas.

\section{METHODS}

\section{Geographical Area}

Ellisras is a deep rural area situated within the north-western area of the Limpopo Province, South Africa. The population is about 50,000 people residing in 42 settlements (10). These villages are approximately $70 \mathrm{~km}$ from the Ellisras town $\left[23^{\circ} 40 \mathrm{~S} 27^{\circ} 44 \mathrm{~W}\right]$, now known as Lephalale, adjacent to the Botswana border. The Iscor coal mine, Matimba and Medupi electricity power station are the major sources of employment for many of the Ellisras residents, whereas the remaining workforce is involved in subsistence farming and cattle rearing, while a minority is in education and the civil service. Unemployment, poverty and low life expectancy seem to play a significant role in the rural South African population which Ellisras rural area people are not an exception (11).

\section{Sampling}

The Ellisras Longitudinal Study [ELS] followed a cluster sampling method initially (12). A total of 773 children [400 boys and 373 girls], aged 6-13 years, who participate in the ELS for anthropometric measurements and dietary survey were included in the analysis. The Ethics Committee of the University of Limpopo granted ethical approval prior to the survey 
and the parents or guardians provided informed consent. The children and their parents signed the assent form after receiving verbal assent from the project principal investigator.

\section{Anthropometrics}

All children underwent measurements of stature, weight, body circumferences [flexed and tensed arm and calf], breadth [bi-epicondyllar humerus and femur], and skinfolds [triceps, subscapular, supraspinale and medial calf] according to the standard procedures of the International Society for the Advancement of Kinathropometry [ISAK] (13). A Martin anthropometer was used to measure stature to the nearest $0.1 \mathrm{~cm}$, a sliding caliper for breadth measurements taken to the last $0.1 \mathrm{~cm}$, and happened [John Bull] skinfold calipers with an inter jaw pressure of $10 \mathrm{~g} \mathrm{~mm}^{2}$ surface jaw area for skinfold measurements to the nearest $0.1 \mathrm{~mm}$. BMI was calculated as stature $[\mathrm{m}]$ divided by weight $[\mathrm{kg}]$ squared.

All the subjects were categorized using the Heath-Carter anthropometric somatotype method (1). This method was reported to be applicable for the description of variation in the human species regardless of age, sex or differences attributed to climate, diet, genetics, race, health or physical activity $(1,14,15)$.

\section{Dietary Intake}

Diet was measured using the 24 hours recall method, which is a valid method to determine group dietary intakes (16). Senior Northern Sotho speaking dietetic students of the University of Limpopo, specifically trained in using socioeconomic questionnaire and the 24-hour recall method, interviewed the parent/caregiver at home on the dietary intake of the children over the previous 24 hours. Estimated portion sizes of foods consumed were recorded in as much as detail as possible, using a pre-tested questionnaire and food models simulating average portions of local foods (17). The parents/caregivers were interviewed twice to control for 
differences between weekdays and weekend days. Dietary data was analyzed using food tables and software $(17,18)$.

\section{Quality Control}

Before commencement of the survey all team members participated in an intensive 2-week training course conducted by one of the researchers KDM [ISAK level-3] instructor. The mean intra-tester technical error of the mean [TEM] [among three measurements by an anthropometrist at the same station] was 0.5 units for endomorphy, 0.13 for mesomorphy and 0.03 for ectomorphy. The inter-tester [anthropometrist and level-3 instructor] mean TEM for somatotype components was $0.13,0,10$, and 0.05 , respectively.

\section{Statistical Analysis}

All analysis was performed using SPSS Version 21 [SPSS Inc., Chicago, IL, USA]. The international cut-off points for thinness [grade one, two and three] by sex for exact ages defined to pass through BMI of 16,17 and $18 \mathrm{~kg} / \mathrm{m}^{2}$ were used together with obesity and overweight $(19,20)$. Data were shown as mean and standard deviation if normally distributed or median and inter-quartile range $\left[25^{\text {th }}\right.$ and $75^{\text {th }}$ percentile $]$ in case of non normal distribution by nutritional status [severe, moderate, mild and overweight/obesity]. The recommended daily dietary allowance according to the Food and Agriculture Organization (18) was used as cut-off points for high and low dietary intake by the nutritional status. Linear regression was first used to calculate the crude analysis and secondly adjusted for age, gender, household income, somatotype category and nutritional status in order to determine the association between somatotype [independent variables] components and macronutrients [independent variables]. A logistic regression analysis was performed, with BMI as a dichotomous dependent variable [the BMI group[s] [severe, moderate and mild under 
nutrition] with the highest prevalence vs. the group[s] with the lowest prevalence of dietary intake. This analysis gave unadjusted and adjusted [age, gender, household income, somatotype category and nutritional status] odds ratios for each of the independent variables in the model. The level of significance was set at $p<0.05$.

\section{RESULTS}

Tables 1 and 2 show the descriptive statistics for absolute body size, somatic variables and dietary intake of Ellisras rural children aged 6 to 13 years old by nutritional status. The ectomorphy rating was significantly high [6.3 [sd 0.9]] in the mild group compared to the normal [4.0 [sd 0.6]], moderate [5.6 [sd 0.8$]$, severe [5.0 [sd 0.7]] and obese group [2.6 [0.7]]. A significant high total Protein intake was recorded in the obese/overweight group [31.3 [IntQ10.2; 53.0]] compare to the normal [22.6 [IntQ 12.2; 39.4]], mild [24.0 [IntQ 13.6; 36.8]], moderate [22.7 [IntQ 13.8; 34.4]] and severe groups [25.0 [IntQ15.2; 38.5]]. However there was low significant intake of Vitamin $\mathrm{E}$ in the obese group [1.2 [IntQ 0.7; 11.2] compared to all other groups [ranges from $1.3[0.8 ; 5.2$ to $2.3[0.8 ; 10.1]$.

Table 1: Descriptive statistics for absolute body size and somatotype by nutritional status* of Ellisras rural children aged 3 to 13 years

\begin{tabular}{llllll}
\hline Variables & Normal & Mild & Moderate & Severe & $\begin{array}{l}\text { Obesity/ } \\
\text { overweight }\end{array}$ \\
& M(sd) & M(sd) & M(sd) & M(sd) & M(sd) \\
\hline Number & 233 & 303 & 157 & 69 & 11 \\
Mean age & $10.3 \pm 1.85$ & $10.5 \pm 1.79$ & $10.3 \pm 2.08$ & $10.8 \pm 2.08$ & $11.0 \pm 1.56$ \\
Absolute body size & & & & & \\
Weight $(\mathrm{kg})$ & $30.9 \pm 6.4$ & $23.2 \pm 4.4$ & $26.2 \pm 5.2$ & $27.2 \pm 5.2$ & $44.3 \pm 4.3$ \\
Height $(\mathrm{cm})$ & $139.0 \pm 10.7$ & $135.1 \pm 10$. & $138.2 \pm 11$. & $137.2 \pm 10.6$ & $150.6 \pm 8.2$ \\
& & 6 & 5 & & \\
BMI $(\mathrm{kg} / \mathrm{m} 2)$ & $15.9 \pm 1.2$ & $12.6 \pm 0.7$ & $13.6 \pm 0.7$ & $14.3 \pm 0.8$ & $19.8 \pm 0.7$
\end{tabular}




\section{Somatotype}

$\begin{array}{llllll}\text { Endomorphy } & 2.6 \pm 0.8 & 1.8(0.5 & 2.0 \pm 0.5 & 2.1 \pm 0.6 & 4.7 \pm 1.1 \\ \text { Mesomorphy } & 3.8 \pm 0.6 & 2.5 \pm 0.7 & 2.9 \pm 0.7 & 3.2 \pm 0.7 & 4.6 \pm 0.5 \\ \text { Ectomorphy } & 4.0 \pm 0.6 & 6.3 \pm 0.9 & 5.6 \pm 0.8 & 5.0 \pm 0.7 & 2.6 \pm 0.7\end{array}$

$\mathrm{M}=$ mean, sd=standard deviation, * nutritional status cut-off values defined by Cole et al. (2000) and (2007),

Table 2: Descriptive statistics for Dietary intake by nutritional status* of Ellisras rural children aged 3 to 13 years

\begin{tabular}{|c|c|c|c|c|c|}
\hline \multirow[t]{3}{*}{ Variables } & Normal & Mild & Moderate & Severe & $\begin{array}{l}\text { Obesity/ } \\
\text { overweight }\end{array}$ \\
\hline & Median+ & Median+ & Median+ & Median+ & Median+ \\
\hline & IQR & IQR & IQR & IQR & IQR \\
\hline \multirow[t]{2}{*}{ Energy } & $3128.5+$ & $3589.0+$ & $3463.0+$ & $3318+$ & $4116.0+$ \\
\hline & $2267 ; 4532$ & $2361 ; 4658$ & $2359 ; 4607$ & $\begin{array}{l}2360.3 ; 4475 \\
3\end{array}$ & $1498 ; 6035$ \\
\hline \multirow[t]{2}{*}{ Carbohydrates } & $134.6+$ & $146.9+$ & $138.1+$ & $141.0+$ & $193+$ \\
\hline & $100.9 ; 189.2$ & $111.5 ; 186.3$ & $104.4 ; 196.3$ & $101.6 ; 188.3$ & $72.7 ; 254.6$ \\
\hline \multirow{2}{*}{$\begin{array}{l}\text { \%Carbohydrate } \\
\text { s }\end{array}$} & $76.1+$ & $73.2+$ & $75.0+$ & $75.5+$ & $77.6+$ \\
\hline & $65.4 ; 84.2$ & $66.0 ; 84.2$ & $64.5 ; 83.1$ & $64.7 ; 83.7$ & $57.3 ; 90.2$ \\
\hline $\operatorname{RDA}(\%)$ & $55-75$ & & & & \\
\hline \multirow[t]{2}{*}{ Total Protein } & $22.6+$ & $24.0+$ & $22.7+$ & $25.0+$ & $31.3+$ \\
\hline & $12.2 ; 39.4$ & $13.6 ; 36.8$ & $13.8 ; 34.4$ & $15.2 ; 38.5$ & $10.2 ; 53.0$ \\
\hline$\%$ Total Protein & $11.9+8.9 ; 15.5$ & $\begin{array}{l}10.8+8.8 ; 13 \\
.7\end{array}$ & $\begin{array}{l}10.8+8.9 ; 14 \\
.8\end{array}$ & $12.3+9.1 ; 15.7$ & $11.4+8.9 ; 16$ \\
\hline RDA ( \%) & $10-15$ & & & & \\
\hline Plant Protein & $15.3+10.5 ; 23.9$ & $\begin{array}{l}17.1+12.2 ; 2 \\
3.7\end{array}$ & $\begin{array}{l}16.2+11.3 ; 2 \\
1.2\end{array}$ & $\begin{array}{l}16.7+10.7 ; 2 \\
3.0\end{array}$ & $\begin{array}{l}21.9+7.5 ; 29 \\
8\end{array}$ \\
\hline
\end{tabular}




$\begin{array}{llllll}\text { \%Plant Protein } & 8.6+6.6 ; 10.2 & 8.4+6.8 ; 10 . & 8.3+6.5 ; 9.7 & 8.2+6.8 ; 10 . & 7.8+5.0 ; 10.2 \\ & & 1 & & 2 & \\ \text { Animal Protein } & 0.7+0 ; 15.6 & 1.7+0 ; 13.2 & 1.1+0 ; 15.9 & 2.3 \pm 0 ; 17.0 & 9.1+0 ; 23.1 \\ \text { \%Animal } & 0.6+0 ; 6.7 & 0.9+0 ; 4.9 & 0.8+0 ; 7.1 & 1.1+0 ; 7.3 & 3.9+0 ; 10.2\end{array}$

Protein

Total fat

$12.0+5.3 ; 25.2 \quad 13.8+6.5 ; 28$

$14.1+6.5 ; 27$ $\begin{array}{ll}.2 & .7\end{array}$

$12.7+6 ; 22.5 \quad 13.4+3.0 ; 31$. $.7 \quad 4$

$\%$ total fat

$13.3+7.6 ; 24.1$

$15.1+8.2 ; 24$ .5

$15.6+9.1 ; 24$

$13.7+8.1 ; 22 \quad 11.6+7.0 ; 32$ .0 .6 3

$\operatorname{RDA}(\%) \quad 15-30$

Saturated fat

$2.8+1.2 ; 5.7$ $3.5+1.3 ; 6$. 2

$3.1+$

$3.2+1.2 ; 5.7$

$5.1+0.5 ; 8.1$

$2 \quad 1.5 ; 6.7$

$\%$ saturated fat

$3.2+1.8 ; 5.5$

$3.6+2.0 ; 5 . \quad 3.4+$

$4 \quad 2.3 ; 5.9$

$3.4+1.7 ; 5.7$

$4.9+1.0 ; 5.2$

$\operatorname{RDA}(\%) \quad<10$

Monounsaturate $\quad 3.2+1.5 ; 6.8$

$4.0+$

$1.7 ; 7.4$

$4.2+1.7 ; 7$

$3.4+1.5 ; 6.7$

$3.8+1.2 ; 11.2$

d fat

$3.6+2.1 ; 6.8$

$4.5+$

$4.4+$

$3.9+2.1 ; 6.5$

$2.8+2.1 ; 7.6$

$2.6 ; 6.5$

$2.8 ; 6.8$

Polyunsaturated $\quad 3.6+1.5 ; 7.9$

$4.3+1.7 ; 12$

.7

$4.2+$

$2.0 ; 8.8$

\%PUNF

$3.5+2.5 ; 7.8$

$4.1+$

$4.3+2.6 ; 9$.

$3.7+2.5 ; 7.6$

$3.4+2.6 ; 17.3$ $2.5 ; 11.3$

8

RDA (\%) 6-10

Total sugar

$71.6+0 ; 95.6$

$71.6+46.4 ; 9$

$71.6+0 ; 95$

$71.6+12.0 ; 95$

$69.6+59.6 ; 9$ 5.6 6 6

5.6

$\%$ sugar

$7.9+0 ; 13.7$

$8.9+$

$2.9 ; 13.6$

$7.2+0 ; 15.5 \quad 7.9+1.7 ; 13.6$

$11.7+5.0 ; 17$.

$\operatorname{RDA}(\%)<10$

Cholesterol

$2+0 ; 59.8$

$6.0+0 ; 59$

$2+0 ; 57.5$

$3.5+0 ; 69.5$

$41+0 ; 185.0$

(mg)

RDA (mg) $\quad<300$

Fibre

$7.8+5.3 ; 12.4$

$8.7+(5.9 ; 12.9$

$8.4+5.4 ; 12$

$8.8+$ $10.8+1.8 ; 16$ .3 $5.6 ; 13.4$ 4 


$\begin{array}{llllll}\text { Iron } & 4.4+2.2 ; 8.7 & 5.0+2.6 ; 8.7 & \begin{array}{l}3.6+2.3 ; 7 . \\ 6\end{array} & \begin{array}{l}4 . \\ 3+2.7 ; 8.3\end{array} & 4.5+2.0 ; 5.9 \\ & & & & & \\ \text { Vitamin A } & 90.5+34.5 ; 609.0 & 83.0+ & 76+22 ; 277 & 72+18 ; 505 & 69.0+0 ; 84.0 \\ & & 23.0 ; 292.0 & & .8 & \\ \text { Vitamin E } & 1.3+0.8 ; 5.2 & 2.3+0.8 ; 10.1 & \begin{array}{l}2.2+0.8 ; 8 . \\ 1\end{array} & \begin{array}{l}1.5+0.8 ; 5 . \\ 2\end{array} & 1.2+0.7 ; 11.2 \\ & & & & & \end{array}$

$\mathrm{RDA}=$ Recommended daily allowance according to the food the food and Agriculture organization (FAO, 2003), \#= median (25 and 75 percentile), * nutritional status cut-off values defined by Cole et al. (2000) and (2007), MUNF= Monounsaturated fat, PUNF= Polyunsaturated fat

Table 3 shows the prevalence of dietary intake based on the recommended daily allowance according to the food and Agriculture Organization [FAO, 2003] by nutritional status of Ellisras rural children aged 3 to 13 years. The prevalence of low Protein intake was significantly high in the mild group [47.6\%] compared to other groups [ranges from $28.6 \%$ to $37.3 \%$ ] while that of low polyunsaturated fat was significantly high [71.4\%] in the obese group compared to all other groups [ranges from 60.0 to $70.3 \%$ ].

Table 3: The prevalence of dietary intake based on recommended daily allowance according to the food and Agriculture organization (FAO, 2003) by nutritional status ${ }^{\# \&}$.

\begin{tabular}{llllll}
\hline Variables & Normal & Mild & Moderate & Sever & $\begin{array}{l}\text { Obesity/overweigh } \\
\mathbf{t}\end{array}$ \\
& $\mathbf{N = 2 3 3}$ & $\mathbf{N = 3 0 3}$ & $\mathbf{N = 1 5 7}$ & $\mathbf{N = 6 9}$ & $\mathbf{N = 1 1}$ \\
& $\mathbf{\% + n}$ & $\mathbf{\%}(\mathbf{n})$ & $\mathbf{\%}(\mathbf{n})$ & $\mathbf{\%}(\mathbf{n})$ & $\mathbf{\%}(\mathbf{n})$ \\
\hline High Cholesterol & $5.2+11$ & $5.7+6$ & $4.4+6$ & $6.4+20$ & $14.3+1$ \\
Low fat & $29.2+62$ & $41.0+43$ & $38.7+53$ & $33.3+104$ & $14.3=1$ \\
High fat & $13.2+28$ & $9.5+10$ & $13.1+18$ & $11.5+36$ & $28.6+2$ \\
Low Protein & $37.3+79$ & $47.6+50$ & $36.5+50$ & $40.4+126$ & $28.6+2$ \\
High Protein & $26.4+56$ & $14.3(15$ & $24.1+33$ & $28.8+90$ & $28.6+2$
\end{tabular}




$\begin{array}{llllll}\text { Low carbohydrates } & 33.0+70 & 45.7+48 & 38.0+52 & 37.5+117 & 28.6+2 \\ \text { High carbohydrates } & 53.8+114 & 46.749 & 50.4+69 & 51.3+160 & 57.1+4 \\ \text { High sugar } & 41.0+87 & 45.7+48 & 40.1+55 & 40.4+126 & 57.1+4 \\ \text { High saturated fat } & 5.2+11 & 1.9+2 & 6.6+9 & 5.1+16 & 14.3+1 \\ \text { Low } & 70.3+149 & 60.0+63 & 61.3+84 & 67.3+210 & 71.4+5 \\ \text { polyunsaturated fat } & & & & & \\ \begin{array}{l}\text { High } \\ \text { Polyunsaturated fat }\end{array} & 18.9+40 & 26.7+28 & 24.8+34 & 18.3+57 & 28.6+2 \\ \end{array}$

\#The international cut-off points for thinness grade one, two and three by sex for exact ages defined to pass through BMI of 16, 17 and 18 were used (Cole et al., 2007)), \&= Overweight and obese according to the Cole et al. (2000) cut-off point

Multiple regression model for crude and adjusted regression coefficients, 95\% confidence interval and p-values for the association of between somatotype components and macronutrients variables of Ellisras rural children are presented in Table 4. Ellisras rural children showed that total Protein [Beta=0.002 95\%CI 0.00 to 0.004] and Energy [Beta= $0.00195 \% \mathrm{CI} 0.00$ to 0.010$]$ were significantly $[\mathrm{P}<0.05]$ related to endomorphy for unadjusted while Viatmine E [Beta $=0.0195 \%$ CI 0.00 to 0.02$]$ was significantly $[\mathrm{P}<0.04]$ associated with ectomorphy unadjusted for age, gender, household income, somatotype category and nutritional status [Table 4].

The logistic regression analysis with BMI as dichotomous dependent variable showed significant results only low fat [Odds ratio $=1.35$ 95\%CI 0.96 to 1.90 ] and high sugar [Odds ratio $=0.9095 \% \mathrm{CI} 0.74$ to 1.41$]$ while the adjusted for age, gender, household income, somatotype category and nutritional status did not yield any significant results [Table 5]. 
Table 5: Results of logistic regression analyses regarding the association between BMI (high versus low) and dietary intake of Ellisras children.

\section{Unadjusted}

\begin{tabular}{|c|c|c|c|c|c|c|c|c|}
\hline \multirow{3}{*}{$\begin{array}{l}\text { Variables } \\
\text { High Cholesterol }\end{array}$} & \multirow{3}{*}{$\begin{array}{l}\text { Unadjusted } \\
\text { Odds ratio } \\
1.147\end{array}$} & \multirow{3}{*}{$\begin{array}{l}\begin{array}{l}\text { P- } \\
\text { value }\end{array} \\
0.711\end{array}$} & \multirow{2}{*}{\multicolumn{2}{|c|}{$95 \% \mathrm{CI}$}} & \multicolumn{4}{|c|}{$\begin{array}{l}\text { Adjusted for age, gender, household } \\
\text { income, somatotype category and } \\
\text { nutritional status }\end{array}$} \\
\hline & & & & & Odds ratio & & $95 \% \mathrm{Cl}$ & \\
\hline & & & $\begin{array}{l}0.56 \\
6\end{array}$ & 2.303 & 1.080 & 0.843 & 0.510 & 2.281 \\
\hline Low fat & 1.351 & 0.05 & $\begin{array}{l}0.95 \\
9\end{array}$ & 1.903 & 1.239 & 0.248 & 0.861 & 1.783 \\
\hline High fat & 0.876 & 0.584 & $\begin{array}{l}0.54 \\
6\end{array}$ & 1.407 & 0.735 & 0.229 & 0.445 & 1.214 \\
\hline Low Protein & 1.153 & 0.392 & $\begin{array}{l}0.83 \\
3\end{array}$ & 1.596 & 1.117 & 0.534 & 0.788 & 1.581 \\
\hline High Protein & 0.926 & 0.677 & $\begin{array}{l}0.64 \\
6\end{array}$ & 1.328 & 0.940 & 0.752 & 0.639 & 1.382 \\
\hline Low carbohydrates & 1.299 & 0.123 & $\begin{array}{l}0.93 \\
1\end{array}$ & 1.812 & 1.215 & 0.284 & 0.851 & 1.736 \\
\hline High carbohydrates & 0.869 & 0.384 & $\begin{array}{l}0.63 \\
3\end{array}$ & 1.192 & 1.004 & 0.982 & 0.714 & 1.411 \\
\hline High sugar & 0.901 & 0.021 & $\begin{array}{l}0.74 \\
0\end{array}$ & 1.407 & 0.995 & 0.997 & 0.705 & 1.404 \\
\hline High saturated fat & 0.960 & 0.911 & $\begin{array}{l}0.46 \\
9\end{array}$ & 1.964 & 0.834 & 0.645 & 0.385 & 1.808 \\
\hline $\begin{array}{l}\text { Low } \\
\text { polyunsaturated fat }\end{array}$ & 0.709 & 0.132 & $\begin{array}{l}0.54 \\
7\end{array}$ & 1.082 & 0.886 & 0.514 & 0.616 & 1.274 \\
\hline $\begin{array}{l}\text { High } \\
\text { polyunsaturated fat }\end{array}$ & 1.182 & 0.410 & $\begin{array}{l}0.71 \\
4\end{array}$ & 1.762 & 1.060 & 0.788 & 0.625 & 1.616 \\
\hline
\end{tabular}




\section{DISCUSSION}

The aim of the study was to determine the relationship between somatotype and dietary intake of 6 to 13 years old primary school children in Ellisras rural areas. Polyunsaturated fat and energy were related to endomrophy while Vitamine E was significantly related to ectomorphy. The prevalence of low polyunsaturated fat was high in the obese group compared to other groups.

Reported energy intakes and micronutrients obtained in the present study were lower than those described by other South African studies for both boys and girls (21-24). However mean Vitamine E intakes of the present sample were comparable to the findings of Kruger et al. (25) and Labadarios et al. (9). This low micro nutrients and energy intakes may in part have been due to under reporting by the respondents on the quantitative food frequency questionnaire [QFFQ]. The validation study showed that the QFFQ tend to under report energy intakes relatives to seven-day weighed records (25).

The reported mean somatotype in the current sample exhibited high ectomorphy ratings followed by mesomorphy while the endomorphy rating show the least values. Similar results were obtained in the Bulgarian boys and girls with endomorphy ranged from 1.5 to 2.1 for boys and 2.0 to 2.9 for girls and mesomorphy ranged from 2.9 to 3.9 for boys and 2.5 to 3.5 for girls and mean ectomorphy ranges from 4.2 to 5.7 for boys and 4.3 to 5.8 for girls (26). The possible explanation for this somatotype classification could be the low energy and micro nutrients intakes experience by the Ellisras children (5).

It is clear from Monyeki et al. (27) that there is a considerable instability of individual somatotypes compared with group changes with the samples becoming more ectomorphic with ages. In the present sample, mesomorphy declines with increasing age even though it is 
known that bone mass and muscles mass increases with increasing age (1). This is probably because of the high prevalence of malnutrition reported in the present sample and in rural South African children $(9,28,29)$.

\section{Limitation of the Study}

In South Africa, changing social, political and economic factors have resulted in increased urbanization and progress in the infrastructure (25). This country's transition implicates that South Africa is becoming more and more a developed country, which is illustrated by western influences regarding diet and other health behaviors. However, when the results of the present study were compared with findings from other studies in developed countries (3033) one arrived at different conclusions. That is, the low energy intake and low macronutrients daily intake as set up by the FAO and low prevalence of overweight and obesity. This could be explained by the fact that the data of this research was collected in 1999, which constitute a methodological limitation of the present study. It is possible that nowadays the above mentioned changes and developments in South Africa have leaded to other nutritional patterns and weight status in rural children.

\section{CONCLUSION}

Total protein and energy intake were significantly $[\mathrm{P}<0.01]$ positively related to endomorphy while Vitamin E was significantly $[\mathrm{P}<0.04]$ associated with ectomorphy. The prevalence of overweight was high for girls compared to Ellisras boys who were mostly ectomorphic. Save walking or cycling trails within Ellisras should be provided to encourage physical activity amongst these children Future research should clarify how healthy are these children and how 
healthy is their lifestyle with respect to physical activity, smoking and alcohol consumption today.

\section{ACKNOWLEDGEMENT}

The financial support received from Vrije University, Amsterdam, The Netherlands and the University of the North, South Africa National Research Foundation and the Medical Research Council of South Africa for the Ellisras Longitudinal Study is also acknowledged with gratitude. Any opinion, findings and conclusions or recommendations expressed in this material are those of the authors and therefore the above mentioned funding sources do not accept any liability in regard thereto. The authors are in depth to Ellisras Longitudinal Study administrators [Seleka PS, Makata TT, Mojela S and Tselapedi T] for providing technical support in preparation of this manuscript.

\section{Conflict of interest: None}

\section{Funding:}

This work was supported by South African National Research Foundation [grant: URD2002050400168], University of Limpopo [Grant number: 1404], Vu Medical University, Amsterdam [grant: UNIN Health Project under VUA Foundation funds]. 


\section{REFERENCES}

1. Carter JEL, Heath BH. Somatotyping - Developments and applicants. Cambridge: Cambridge University press, 1990.

2. Gurney M, Gorstein J. The global prevalence of obesity- An initial overview of available data. World Health Stat Q 1988; 41: 251-254.

3. O'Dea JA. Prevention of child obesity: "First, do no harm". Health Educ Res 2005; 20: 259-265.

4. Dietz WH. Health consequences of obesity in youth: childhood predictors of adult disease. Pediatrics 1998; 101, 518-525.

5. Monyeki KD, Kemper HCG \& Twisk JWR. Trends in obesity and hypertension in South African youth. In O`Dea JA and Eriksen M. (Eds) Childhood obesity prevention International Research, controversies and interventions. New York: Oxford University Press, 2010

6. Ho FT. Cardiovascular risks associated with obesity in children and adolescents. Ann Acad Med 2009; 38, 48-56.

7. Kemper HCG (2004) Amsterdam growth and Health longitudinal study: A 23 year follow up from teenager to adult about lifestyle and health. Karger: New York, pp. 1-20.

8. Jinabhai ICC, Taylor M, Preddy P, Monyeki D, Kamabaran N, Omardien R, Sullivan KR.

Sex differences in under and over nutrition among school -going Black teenagers in South Africa: An uneven nutrition trajectory. Trop Med Int Health 2007; 12, 944-952 
9. Labadarios D, Steyn NP, Maunder E, MacIntyre, U, Swart, R, Gericke, G. The National Food Consumption survey: Children aged 1 -9 years, South Africa, 1999. Department of Health, Pretoria (Chapter 2), 2000.

10. Sidiropoulos E, Jeffery, A, Mackay, Gallocher R, Forgey H, Chips, C. South Africa Survey 1995/1996. Johannesburg: South African Institute of Race and Relations. 234360pp, 1996.

11. Bradshaw D, Steyn K. Poverty and chronic disease in South Africa. Technical Report. Cape Town: South African Medical Research Council, 2001.

15. Monyeki KD, Cameroon N, Getz B. Growth and nutritional status of rural South African children 3-10 years old: The Ellisras Growth Study. Am J Hum Biol 2000; 12, 42-49.

16. Norton K, Olds T. Anthropometrical. Sydney: University of New South Wales Press, 1996.

17. Heath BH, Carter JEL. Growth and Somatotype patterns of Manus children, Territory of Paua and New Guinea: Applications of a modified somatotype method to the study of growth patterns. Am J Phys Anthropol 1971; 35, 49-68.

18. Hebbelinck M, Duquet W, Ross WD. A practical outline for the Heath-Carter Somatotyping method applied to children. In: Pediatric Work Physiology Proceedings, $4^{\text {th }}$ International Symposium, Israel: Wingate Institute, 1973

19. Truswell S, Mann J (eds). Essentials of Human Nutrition. Oxford: Oxford University press, 1998. 
20. Langenhoven M, Kruger M, Gouws E, Faber, M. MRC Food composition Tables ( ${ }^{\text {rd }}$ ed.). Parow: Research Institute for Nutritional Disease, South African Medical Research Council, 1991.

21. Food and Agriculture Organization. WHO. Technical Report Series 916. Diet, Nutrition and the Prevention of Chronic Diseases: Report of a Joint WHO/FAO. Expert Consultation, Chapter 5, 2003.

23. Cole TJ, Flegal KM, Nicholls D, Jackson AA. Body mass index cutt offs to define thinness in children and adolescents: International survey. BMJ 2007; 335 :166-167.

24. Cameron N. Commentary on: Body mass index cut- offs to define thinness in children and adolescents: International survey. BMJ 2007; 335: 166-167.

25. MacIntyre UE, Kruger SH, Venter HH, Vorster HH. Dietary intake of an African population in different stages of transition in the North West Province, South Africa: the THUSA study. Nutrition 2002; 22: 239-256.

26. Kruger R, Kruger HS, MacIntyre UE. The determinants of overweight and obesity among 10-15 year olds schoolchildren in the North West Province, South Africa- the Thusa Bana (Transition and Health during urbanization of South Africans; BANA, children) study. Public Health Nutr 2006; 9: 351-358.

27. Steyn NP, Badenhost CJ, Nel JH.The nutritional status of Pedi pre-school children in two rural areas of Lebowa. S A J Sc Nutr 1992; 4: 24-28.

28. Steyn NP, Bradshaw D, Norman R. Dietary Changes and the Health Transition in South Africa: Implications for Health Policy. Cape Town: South African Medical Research Council, 2006. 
29. Kruger HS, Kruger A, Vorster HH. Urbanization of African in the North West Province is associated with better micronutrient status: the Transition and Health during Urbanization Study in South Africa. Nutrition 2005; 25, 265-375.

30. Koleva M, Nacheva A, Boev M. Somatotype, nutrition and obesity: Bulgaria: Rev Environ Health 2000, 15, 389-98.

31. Monyeki KD, de Ridder JH, Steyn NP.Stability of somatotypes in 4 to 10 year-old rural South African girls. Ann Hum Biol 2002; 29: 37-49.

32. Monyeki KD, Monyeki M, Brits SJ. Development and Tracking of Body Mass Index from Preschool Age into Adolescence in Rural South African Children: Ellisras Longitudinal Growth and Health Study. J Health Popul Nutr 2008; 4: 405-417.

33. Reddy SP, Panday S, Swart D.Umthenthe Uhlaba Usamali-The South African Youth Risk Behavior survey 2002. Cape Town: South African Medical Research Council, 2003. 
Table 4: Results of linear regression analysis regarding the association between somatotype and dietary intake of Ellisras children

\begin{tabular}{|c|c|c|c|c|c|c|c|c|c|c|c|c|c|c|c|c|c|c|}
\hline \multirow[b]{4}{*}{ Energy } & \multirow{2}{*}{\multicolumn{6}{|c|}{$\begin{array}{l}\text { Unadjusted } \\
\text { Endomorphy }\end{array}$}} & & & & \multicolumn{9}{|c|}{$\begin{array}{l}\text { Adjusted for age, gender, household income, somatotype } \\
\text { category and nutritional status }\end{array}$} \\
\hline & & & & & & & \multicolumn{3}{|c|}{ Ectomorphy } & \multicolumn{3}{|c|}{ Endomorphy } & \multicolumn{3}{|c|}{ Mesomorphy } & \multicolumn{3}{|c|}{ Ectomorphy } \\
\hline & \multirow{2}{*}{$\begin{array}{l}\text { Beta } \\
0.00 \\
1^{*}\end{array}$} & \multicolumn{2}{|c|}{$95 \% \mathrm{CI}$} & \multirow{2}{*}{$\begin{array}{l}\text { Beta } \\
0.00\end{array}$} & \multicolumn{2}{|c|}{$95 \% \mathrm{CI}$} & \multirow{2}{*}{$\begin{array}{l}\text { Beta } \\
0.00\end{array}$} & \multicolumn{2}{|c|}{$95 \% \mathrm{CI}$} & \multirow{2}{*}{$\begin{array}{l}\text { Beta } \\
0.00\end{array}$} & \multicolumn{2}{|c|}{$95 \% \mathrm{CI}$} & \multirow{2}{*}{$\begin{array}{l}\text { Beta } \\
0.000\end{array}$} & \multicolumn{2}{|c|}{$95 \% \mathrm{CI}$} & \multirow{2}{*}{$\begin{array}{l}\text { Beta } \\
0.00\end{array}$} & \multicolumn{2}{|c|}{$95 \% \mathrm{CI}$} \\
\hline & & $\begin{array}{l}0.00 \\
1\end{array}$ & $\begin{array}{l}0.01 \\
0\end{array}$ & & $\begin{array}{l}0.00 \\
0\end{array}$ & $\begin{array}{l}0.00 \\
0\end{array}$ & & $\begin{array}{l}0.00 \\
0\end{array}$ & $\begin{array}{l}0.00 \\
0\end{array}$ & & $\begin{array}{l}0.00 \\
0\end{array}$ & $\begin{array}{l}0.00 \\
0\end{array}$ & & $\begin{array}{l}0.00 \\
0\end{array}$ & $\begin{array}{l}0.00 \\
0\end{array}$ & & $\begin{array}{l}0.00 \\
0\end{array}$ & $\begin{array}{l}0.00 \\
0\end{array}$ \\
\hline $\begin{array}{l}\text { Total } \\
\text { carbohydrates }\end{array}$ & $\begin{array}{l}0.00 \\
1\end{array}$ & $\begin{array}{l}0.00 \\
0\end{array}$ & $\begin{array}{l}0.00 \\
1\end{array}$ & $\begin{array}{l}0.00 \\
0\end{array}$ & $\begin{array}{l}0.00 \\
1\end{array}$ & $\begin{array}{l}0.00 \\
1\end{array}$ & $\begin{array}{l}0.00 \\
0\end{array}$ & $\begin{array}{l}0.00 \\
1\end{array}$ & $\begin{array}{l}0.00 \\
1\end{array}$ & $\begin{array}{l}0.00 \\
0\end{array}$ & $\begin{array}{l}- \\
0.00 \\
1\end{array}$ & $\begin{array}{l}0.00 \\
1\end{array}$ & 0.000 & $\begin{array}{l}0.00 \\
0\end{array}$ & $\begin{array}{l}0.00 \\
1\end{array}$ & $\begin{array}{l}0.00 \\
0\end{array}$ & $\begin{array}{l}- \\
0.00 \\
1\end{array}$ & $\begin{array}{l}0.00 \\
1\end{array}$ \\
\hline Total Protein & $\begin{array}{l}0.00 \\
2^{*}\end{array}$ & $\begin{array}{l}0.00 \\
0\end{array}$ & $\begin{array}{l}0.00 \\
4\end{array}$ & $\begin{array}{l}0.00 \\
0\end{array}$ & $\begin{array}{l}- \\
0.00 \\
3\end{array}$ & $\begin{array}{l}0.00 \\
2\end{array}$ & $\begin{array}{l}- \\
0.00 \\
1\end{array}$ & $\begin{array}{l}- \\
0.00 \\
4\end{array}$ & $\begin{array}{l}0.00 \\
2\end{array}$ & $\begin{array}{l}0.00 \\
1\end{array}$ & $\begin{array}{l}- \\
0.00 \\
1\end{array}$ & $\begin{array}{l}0.00 \\
3\end{array}$ & 0.000 & $\begin{array}{l}- \\
0.00 \\
2\end{array}$ & $\begin{array}{l}0.00 \\
2\end{array}$ & $\begin{array}{l}- \\
0.00 \\
1\end{array}$ & $\begin{array}{l}- \\
0.00 \\
4\end{array}$ & $\begin{array}{l}0.00 \\
2\end{array}$ \\
\hline Plant Protein & $\begin{array}{l}0.00 \\
5^{*}\end{array}$ & $\begin{array}{l}- \\
0.00 \\
1\end{array}$ & $\begin{array}{l}0.00 \\
1\end{array}$ & $\begin{array}{l}0.00 \\
3\end{array}$ & $\begin{array}{l}- \\
0.00 \\
3\end{array}$ & $\begin{array}{l}0.00 \\
8\end{array}$ & $\begin{array}{l}- \\
0.00 \\
1\end{array}$ & $\begin{array}{l}0.00 \\
1\end{array}$ & $\begin{array}{l}0.00 \\
6\end{array}$ & $\begin{array}{l}0.00 \\
2\end{array}$ & $\begin{array}{l}- \\
0.00 \\
3\end{array}$ & $\begin{array}{l}0.00 \\
6\end{array}$ & 0.004 & $\begin{array}{l}- \\
0.00 \\
1\end{array}$ & $\begin{array}{l}0.00 \\
1\end{array}$ & $\begin{array}{l}- \\
0.00 \\
1\end{array}$ & $\begin{array}{l}- \\
0.00 \\
8\end{array}$ & $\begin{array}{l}0.00 \\
6\end{array}$ \\
\hline Animal Protein & $\begin{array}{l}0.00 \\
2\end{array}$ & $\begin{array}{l}- \\
0.00 \\
1\end{array}$ & $\begin{array}{l}0.00 \\
4\end{array}$ & $\begin{array}{l}- \\
0.00 \\
1\end{array}$ & $\begin{array}{l}- \\
0.00 \\
3\end{array}$ & $\begin{array}{l}0.00 \\
1\end{array}$ & $\begin{array}{l}- \\
0.00 \\
1\end{array}$ & $\begin{array}{l}- \\
0.00 \\
4\end{array}$ & $\begin{array}{l}0.00 \\
2\end{array}$ & $\begin{array}{l}0.00 \\
1\end{array}$ & $\begin{array}{l}- \\
0.00 \\
1\end{array}$ & $\begin{array}{l}0.00 \\
3\end{array}$ & 0.000 & $\begin{array}{l}- \\
0.00 \\
3\end{array}$ & $\begin{array}{l}0.00 \\
2\end{array}$ & $\begin{array}{l}- \\
0.00 \\
1\end{array}$ & $\begin{array}{l}- \\
0.00 \\
5\end{array}$ & $\begin{array}{l}0.00 \\
2\end{array}$ \\
\hline Total fat & $\begin{array}{l}0.00 \\
2\end{array}$ & $\begin{array}{l}- \\
0.00 \\
1\end{array}$ & $\begin{array}{l}0.00 \\
5\end{array}$ & $\begin{array}{l}- \\
0.00 \\
2\end{array}$ & $\begin{array}{l}- \\
0.00 \\
5\end{array}$ & $\begin{array}{l}0.00 \\
1\end{array}$ & $\begin{array}{l}0.00 \\
3\end{array}$ & $\begin{array}{l}- \\
0.00 \\
2\end{array}$ & $\begin{array}{l}0.00 \\
7\end{array}$ & $\begin{array}{l}0.00 \\
2\end{array}$ & $\begin{array}{l}0.00 \\
1\end{array}$ & $\begin{array}{l}0.00 \\
4\end{array}$ & -0.003 & $\begin{array}{l}- \\
0.00 \\
5\end{array}$ & $\begin{array}{l}0.00 \\
1\end{array}$ & $\begin{array}{l}0.00 \\
3\end{array}$ & $\begin{array}{l}- \\
0.00 \\
1\end{array}$ & $\begin{array}{l}0.00 \\
7\end{array}$ \\
\hline Saturated fat & 0.00 & $\overline{-}-00$ & 0.01 & 0.01 & 0.00 & 0.02 & $-\overline{0}-00$ & $-\overline{0}-01$ & 0.00 & 0.01 & 0.00 & 0.02 & -0.002 & $-\overline{0}$ & 0.00 & 0.00 & 0.01 & 0.01 \\
\hline
\end{tabular}




\begin{tabular}{|c|c|c|c|c|c|c|c|c|c|c|c|c|c|c|c|c|c|c|}
\hline & 3 & 6 & 5 & $4 *$ & 3 & 5 & 3 & 5 & 9 & $0 *$ & 2 & 0 & & 4 & 9 & 3 & 6 & 5 \\
\hline $\begin{array}{l}\text { Monounsaturat } \\
\text { ed fat }\end{array}$ & $\begin{array}{l}0.00 \\
6\end{array}$ & $\begin{array}{l}0.00 \\
4\end{array}$ & $\begin{array}{l}0.01 \\
6\end{array}$ & $\begin{array}{l}- \\
0.00 \\
6\end{array}$ & $\begin{array}{l}- \\
0.01 \\
7\end{array}$ & $\begin{array}{l}0.00 \\
4\end{array}$ & $\begin{array}{l}0.00 \\
7\end{array}$ & $\begin{array}{l}- \\
0.00 \\
7\end{array}$ & $\begin{array}{l}0.02 \\
1\end{array}$ & $\begin{array}{l}0.00 \\
4^{*}\end{array}$ & $\begin{array}{l}0.00 \\
4\end{array}$ & $\begin{array}{l}0.01 \\
3\end{array}$ & 0.000 & $\begin{array}{l}- \\
0.00 \\
3\end{array}$ & $\begin{array}{l}0.00 \\
2\end{array}$ & $\begin{array}{l}0.00 \\
1\end{array}$ & $\begin{array}{l}0.00 \\
3\end{array}$ & $\begin{array}{l}0.00 \\
2\end{array}$ \\
\hline $\begin{array}{l}\text { Polyunsaturated } \\
\text { fat }\end{array}$ & $\begin{array}{l}0.00 \\
3\end{array}$ & $\begin{array}{l}- \\
0.00 \\
4\end{array}$ & $\begin{array}{l}0.00 \\
9\end{array}$ & $\begin{array}{l}0.00 \\
5\end{array}$ & $\begin{array}{l}- \\
0.00 \\
1\end{array}$ & $\begin{array}{l}0.00 \\
1\end{array}$ & $\begin{array}{l}0.00 \\
9^{*}\end{array}$ & $\begin{array}{l}0.00 \\
0\end{array}$ & $\begin{array}{l}0.01 \\
8\end{array}$ & $\begin{array}{l}0.00 \\
2\end{array}$ & $\begin{array}{l}- \\
0.00 \\
3\end{array}$ & $\begin{array}{l}0.00 \\
7\end{array}$ & -0.001 & $\begin{array}{l}- \\
0.00 \\
4\end{array}$ & $\begin{array}{l}0.00 \\
2\end{array}$ & $\begin{array}{l}- \\
0.00 \\
2\end{array}$ & $\begin{array}{l}- \\
0.00 \\
5\end{array}$ & $\begin{array}{l}0.00 \\
1\end{array}$ \\
\hline Total sugar & $\begin{array}{l}0.00 \\
0\end{array}$ & $\begin{array}{l}- \\
0.00 \\
1\end{array}$ & $\begin{array}{l}0.00 \\
0\end{array}$ & $\begin{array}{l}0.00 \\
0\end{array}$ & $\begin{array}{l}- \\
0.00 \\
1\end{array}$ & 0.00 & $\begin{array}{l}0.00 \\
0\end{array}$ & $\begin{array}{l}0.00 \\
1\end{array}$ & $\begin{array}{l}0.00 \\
0\end{array}$ & $\begin{array}{l}- \\
0.00 \\
1\end{array}$ & $\begin{array}{l}- \\
0.00 \\
2\end{array}$ & $\begin{array}{l}0.00 \\
1\end{array}$ & $\begin{array}{l}0.001 \\
*\end{array}$ & $\begin{array}{l}- \\
0.00 \\
2\end{array}$ & $\begin{array}{l}0.00 \\
0\end{array}$ & $\begin{array}{l}0.00 \\
0\end{array}$ & $\begin{array}{l}0.00 \\
2\end{array}$ & $\begin{array}{l}0.00 \\
2\end{array}$ \\
\hline Cholesterol & $\begin{array}{l}0.00 \\
0\end{array}$ & $\begin{array}{l}0.00 \\
0\end{array}$ & $\begin{array}{l}0.00 \\
1\end{array}$ & $\begin{array}{l}0.00 \\
0\end{array}$ & $\begin{array}{l}0.00 \\
1\end{array}$ & $\begin{array}{l}0.00 \\
0\end{array}$ & $\begin{array}{l}0.00 \\
0\end{array}$ & $\begin{array}{l}- \\
0.00 \\
0\end{array}$ & $\begin{array}{l}0.00 \\
0\end{array}$ & $\begin{array}{l}0.00 \\
0\end{array}$ & $\begin{array}{l}0.00 \\
0\end{array}$ & $\begin{array}{l}0.00 \\
1\end{array}$ & 0.000 & $\begin{array}{l}- \\
0.00 \\
1\end{array}$ & $\begin{array}{l}0.00 \\
0\end{array}$ & $\begin{array}{l}0.00 \\
0\end{array}$ & $\begin{array}{l}0.00 \\
0\end{array}$ & $\begin{array}{l}0.00 \\
0\end{array}$ \\
\hline Fibre & $\begin{array}{l}- \\
0.00 \\
3\end{array}$ & $\begin{array}{l}- \\
0.01 \\
0\end{array}$ & $\begin{array}{l}0.00 \\
3\end{array}$ & $\begin{array}{l}0.00 \\
3\end{array}$ & $\begin{array}{l}- \\
0.00 \\
4\end{array}$ & $\begin{array}{l}0.00 \\
9\end{array}$ & $\begin{array}{l}0.00 \\
3\end{array}$ & $\begin{array}{l}- \\
0.00 \\
6\end{array}$ & $\begin{array}{l}0.01 \\
2\end{array}$ & $\begin{array}{l}0.00 \\
4\end{array}$ & $\begin{array}{l}- \\
0.00 \\
5\end{array}$ & $\begin{array}{l}0.01 \\
2\end{array}$ & 0.002 & $\begin{array}{l}- \\
0.00 \\
8\end{array}$ & $\begin{array}{l}0.01 \\
1\end{array}$ & $\begin{array}{l}0.00 \\
1\end{array}$ & $\begin{array}{l}- \\
0.00 \\
1\end{array}$ & $\begin{array}{l}0.01 \\
4\end{array}$ \\
\hline Iron & $\begin{array}{l}0.00 \\
5\end{array}$ & $\begin{array}{l}- \\
0.00 \\
1\end{array}$ & $\begin{array}{l}0.01 \\
2\end{array}$ & $\begin{array}{l}0.00 \\
4\end{array}$ & $\begin{array}{l}- \\
0.00 \\
3\end{array}$ & $\begin{array}{l}0.01 \\
0\end{array}$ & $\begin{array}{l}- \\
0.00 \\
1\end{array}$ & $\begin{array}{l}- \\
0.01 \\
0\end{array}$ & $\begin{array}{l}0.00 \\
7\end{array}$ & $\begin{array}{l}0.00 \\
9^{*}\end{array}$ & $\begin{array}{l}0.00 \\
0\end{array}$ & $\begin{array}{l}0.01 \\
7\end{array}$ & 0.006 & $\begin{array}{l}- \\
0.00 \\
3\end{array}$ & $\begin{array}{l}0.01 \\
5\end{array}$ & $\begin{array}{l}- \\
0.00 \\
7\end{array}$ & $\begin{array}{l}0.02 \\
0\end{array}$ & $\begin{array}{l}0.00 \\
6\end{array}$ \\
\hline Vitamin A & $\begin{array}{l}0.00 \\
0\end{array}$ & $\begin{array}{l}0.00 \\
0\end{array}$ & $\begin{array}{l}0.00 \\
1\end{array}$ & $\begin{array}{l}0.00 \\
0\end{array}$ & $\begin{array}{l}0.00 \\
0\end{array}$ & $\begin{array}{l}0.00 \\
01\end{array}$ & $\begin{array}{l}0.00 \\
0\end{array}$ & $\begin{array}{l}0.00 \\
0\end{array}$ & $\begin{array}{l}0.00 \\
1\end{array}$ & $\begin{array}{l}0.00 \\
0\end{array}$ & $\begin{array}{l}0.00 \\
0\end{array}$ & $\begin{array}{l}0.00 \\
0\end{array}$ & 0.000 & $\begin{array}{l}0.00 \\
0\end{array}$ & $\begin{array}{l}0.00 \\
0\end{array}$ & $\begin{array}{l}0.00 \\
0\end{array}$ & $\begin{array}{l}0.00 \\
0\end{array}$ & $\begin{array}{l}0.00 \\
0\end{array}$ \\
\hline Vitamin E & $\begin{array}{l}0.00 \\
1\end{array}$ & $\begin{array}{l}- \\
0.00 \\
6\end{array}$ & $\begin{array}{l}0.00 \\
8\end{array}$ & $\begin{array}{l}- \\
0.00 \\
6\end{array}$ & $\begin{array}{l}- \\
0.01 \\
3\end{array}$ & $\begin{array}{l}0.00 \\
1\end{array}$ & $\begin{array}{l}0.01 \\
*\end{array}$ & $\begin{array}{l}0.00 \\
0\end{array}$ & $\begin{array}{l}0.02 \\
1\end{array}$ & $\begin{array}{l}0.00 \\
2\end{array}$ & $\begin{array}{l}- \\
0.00 \\
4\end{array}$ & $\begin{array}{l}0.00 \\
8\end{array}$ & $\begin{array}{l}- \\
0.007 \\
*\end{array}$ & $\begin{array}{l}- \\
0.00 \\
1\end{array}$ & $\begin{array}{l}0.00 \\
0\end{array}$ & $\begin{array}{l}0.01 \\
1^{*}\end{array}$ & $\begin{array}{l}0.00 \\
1\end{array}$ & $\begin{array}{l}0.00 \\
2\end{array}$ \\
\hline
\end{tabular}


Somatotype and Dietary Intake in Rural South African Children 